\title{
FOR YOUR GREAT AND IMPORTANT DAY: OLD AGE, HUMOR AND ONLINE BIRTHDAY CARDS 1
}

\section{ZDENKO ZEMAN}

Institute of Social Sciences Ivo Pilar, Zagreb

\author{
MARIJA GEIGER ZEMAN \\ Institute of Social Sciences Ivo Pilar, Zagreb
}

\begin{abstract}
Although the category of age is extremely complex, age is usually reduced to chronological age, which is - as the number of years lived from the time of birth (number of birthdays) - the simplest marker of one's age (or old age). Birthday cards are an important aspect of birthdays. They are multifunctional artifacts of popular culture, and their communicational function is the most important one. At the individual level, the sender uses a birthday card to send certain messages to the recipient, and at the sociocultural level, a birthday card transmits socially-created meanings and subjects of age, old age and aging. In this sense, a birthday card is a "ceremonial token" (Ellis and Morrison 2005), which transmits (and reinforces) cultural ideas, meanings, attitudes and messages, i.e. "discourses that form the basis of the social construction of age" (Andrew 2012: 11), where humor plays an especially important role. Previous studies have shown that age-specific humor has positive, ambivalent and, most often, negative aspects. These negative aspects are related to aging stereotypes and distorted meanings that certain cultures attribute to aging and old age, including the gender component. The paper presents the results of an analysis of age-specific humor content present in online birthday cards, with special emphasis placed on: 1) themes and motifs that indicate the dominant and (globally) present narratives about old age and aging, socio-cultural ideas, understanding of and attitudes about aging, old age and older persons; 2) shortterm effects and long-term consequences of this type of humorous content.
\end{abstract}

Keywords: age humor, narratives on aging, online birthday cards, age, chronological age, content analysis

${ }^{1}$ This article is to appear in the edited volume entitled Humor u svakodnevnoj komunikaciji (Humor in Everyday Communication) (Institute of Ethnology and Folklore Research, 2017), and is published here with the permission of the volume editors. 


\section{INTRODUCTION: DOMINANT NARRATIVES ABOUT AGING AND OLD AGE}

The notion of age is neither unambiguous nor simple as may seem at first glance. It is a "multidimensional concept" "that is not independent of time and place" (Wolf 2014: 1). According to Margaret Cruikshank (2009: 2), aging and old age are the "creation of [...] time and place, more cultural than biological". This analytical focus on the cultural aspects of old age and aging represents "the most significant development in age studies", and Margaret Gullette (2015: 21) points to the potentials that these new insights can have in the articulation of various forms of resistance to ageism.

As a relative, variable and context-dependent category, age is saturated with various attitudes, beliefs, dominant discourses (Andrew 2012) and specific narratives. In the context of critical, social and humanist gerontology, two cultural narratives about aging, dominating the sociocultural horizon of the western culture (Sandberg 2013) are present - the narrative of age as decline and the narrative of successful aging. These are reductionist, binary oppositions where aging and old age are considered partially, superficially and inadequately. According to the decline narrative, aging is a process of continual decline of bodily strength and health, which, eventually, necessarily results in old age as a condition characterized by "non-productivity, increasing passivity and dependency" (Sandberg 2013: 11). Opposed to it is the narrative of successful aging which, at first sight, seems to be in stark contrast to seeing aging as decline. On closer scrutiny, the narrative of successful aging, according to Sandberg (ibid.), emerges as being constructed on neoliberal principles and "imperatives of activity, autonomy and responsibility", based on the example (or paradigm) of an individual who manages to keep him/herself youthful in the long term. Thus, the narrative of successful aging does not, in fact, challenge ageism or the age hierarchy in society, because it is based on the idea that youth is a socially desirable state and being (Sandberg 2013: 13; Gullette 2015: 21). This covert acceptance of negative valorization of old age (and its ageist devaluation) has been briefly and effectively summarized by Toni Calasanti and Neal King (quoted in Sandberg 2013: 13) who said that "Successful Aging means not aging".

Given that aging is a multidimensional process not only related to physical processes, we can (and have to) discuss other relevant levels where it is in evidence: the psychological, social and population level. Regardless of how clear this complexity may seem, the prevalent tendency is to perceive age in a static, rigid and reductionist way, i.e. exclusively as chronological or "numerical age" (Moody as quoted in Morgan and Kunkel 2001: 10-11) - the number of someone's (lived) years or the number of (celebrated) birthdays. A birthday is a sort of a "ritual occasion", a special day to celebrate and mark the birth of a person, who, on that - "their own"! day - is accorded the status of a "special" person (Dodson and Belk 1996). This unique characteristic of birthdays has been accurately summarized in the text of a birthday card, which makes it brutally clear what it is all about: "Today is 
all about you. Tomorrow, you're nobody again". ${ }^{2}$ Birthday cards are an important element of birthdays and events surrounding it, as they accurately reflect the societal and cultural narratives and the prevailing social attitudes towards and concepts of aging and old age.

\section{BIRTHDAY CARDS: REFLECTIONS AND COMMENTARIES ON AGING AND OLD AGE}

At the beginning of the 20th century, in the West, the greeting card industry became a profitable industry (Rogan 2005), owing its success to being familiar with the tastes of its potential audience, and with market needs. ${ }^{3}$ During the last century, the range of greeting cards changed, differentiated and specialized, and the same is true of their production, distribution and consumption. In its last decades, the development of the internet and the general advance in digital and communicational technologies greatly contributed to these trends, resulting in the appearance of electronic greeting cards in the late 1990s, which gave a new impetus to the development of this publishing industry. ${ }^{4}$

In addition to the market and marketing component, the socio-cultural component plays a major role in the "greeting card industry" (Loughran 2010; Dodson and Belk 1996). Greeting cards are a way to celebrate holidays and mark significant turning points in people's private lives (such as birthdays, births, weddings, anniversaries, holidays, etc.), and a way to provide the recipient with emotional support, which makes their influence on the recipient significant (Eisenstein-Naveh as cited in Loughran 2010: 633). In this sense, greeting cards, like cards in general, are multifunctional - they are a form of "ritual communication" as well as of "gift exchanges" (Rogan 2005: 1), which means that birthday cards can be considered a form of a "ceremonial gift" (Yan 2005: 246). Sherry (1983: 160) also discusses greeting cards as gifts, stating that any resource - "tangible or intangible" (a thing, experience, service, etc.) - has the potential to transform into a gift. Birthday cards can also be observed from the point of view of commercialized birthday rituals and consumerist practices, within a particular variant of the gift economy which generates "mutually moral obligation" (Clarke 2007: 280). ${ }^{5}$

\footnotetext{
${ }^{2}$ www.scribbler.com.

${ }^{3}$ In Great Britain, the greeting card market is worth 1.6 billion pounds, and (in)directly employs 100,000 people of different professions. It should certainly be pointed out that $85 \%$ of greeting cards are purchased by women, which confirms the results of many earlier studies which show that sending greeting cards is a gendered activity (cf. Greeting Card Association, "Facts and Figures: Latest Figures from the GCA Market Report 2015").

${ }^{4}$ Greeting Card Association "About the industry", http://www.greetingcard.org/industry-resources/ history/.

${ }^{5}$ Gifting has an important place in classical and contemporary anthropological and ethnological studies. Yunxiang Yan (2005: 246) describes gifting as "one of the most important modes of social exchange in human societies", and an activity which "creates, maintains and strengthens various social bonds" and "in turn define[s] the identities of persons". Taking into consideration that there is no universal typology of gifting, Yan (2005: 246-248) makes a distinction between "ceremonial and non-ceremonial gifts", which he
} 
Cards are "an exchange object, a gift, and a message carrier" (Rogan 2005: 2). Their multifunctionality is corroborated by a verbal and/or visual analysis, which reveals multiple deeper meaning levels, and we can consider them, with good reason, artefacts of popular culture which more or less precisely reflect particular values, attitudes and expectations. As has already been said, when it comes to birthday cards, age-related as well as genderrelated expectations are at play. ${ }^{6}$ In certain cases, birthday cards themselves implicitly comment on social attitudes (Cacioppo and Andersen as cited in Loughran 2010: 641). Greeting cards can be (de)coded, interpreted and read like any other cultural text, but it is important to keep in mind their multivocality and ambiguity (Geiger Zeman and Zeman 2011), which is often hidden behind ostensible simplicity.

We have already said several times that birthday cards are multifunctional artefacts of popular culture, but it should be added that they perform their multiple functions on the micro and on the macro level. On the micro level, the private, interpersonal, emotional, communicational, esthetic, remembrance, and identity component manifest themselves. Birthday cards are personal because they enable communication of emotions (Dodson and Belk 1996) and the expression of kindness towards the recipient (Bearon 2005: 58), but this basic communicational fact is built upon or modified by the fact that the sender uses the birthday card to transmit a particular message that will have "an influence on the receiver" (Loughran 2010: 642). In this sense, Ellis and Morrison (2005: 61) say that (birthday) "cards can provide information about the social identity, temperament, intent and expectations of both sender and receiver". Dodson and Belk (1996) stress the remembrance component of birthday cards - by saving birthday cards the recipients preserve the memory of their sender, and document their lives.

On the macro or the socio-cultural level, birthday cards transmit dominant narratives of aging, but may also have a subversive charge which inverts or at least questions the dominant meanings and concepts. If a birthday card transmits socially created and accepted meanings and content concerning age, old age, and aging, its function is apologetic and legitimating. In this sense, birthday cards function as "ceremonial tokens" (Ellis and Morrison 2005: 57, 61) or a "ceremonial gift" (Yan 2005: 246), which transmits (and reinforces) cultural concepts, meanings, attitudes and messages, i.e. "discourses that form the basis

considers basic, and creates several gifting typologies based on several criteria - "the agency of social actors" (gift activities between two persons or collectivistic giving); "the context of social relations" "horizontal and vertical gift exchange"); the gender dimension of gift activities and "economic implications of giving" point to the differences between pre-industrial/small-scale societies and (post)industrial societies.

${ }^{6}$ Generally speaking, the gender component of giving is a significant area of study. Studies in the western society show that women give and receive more gifts than men (Yan 2005: 248), which is confirmed by Theodore Caplow's (1984) study, detailing the economy of Christmas giving in Middletown, where the aspects of hierarchical and vertical giving, as well as the gender and age dimension of giving are evident. According to Cheal, "giving is regarded as an essential part of a feminized ideology of love" (Cheal 1987 as cited in Yan 2005: 248). Micaela di Leonardo (1987: 442-443) studied the forms of female labor of American women of Italian heritage in North California, and she emphasizes the importance of "work of kinship" and maintaining family ties, which includes various types of (in)direct communication, where sending greeting cards plays an important role. 
of the social construction of age" (Andrew 2012: 11). Humor, as has been mentioned, plays a particularly important role in this regard. Thus, it is not at all surprising that numerous earlier studies showed that birthday cards are "indicators of societal attitudes toward aging" (Demos and Jache; Dillon and Jones; Huyck and Duchon; Schrift as cited in Dodson and Belk 1996), but also that "gender-based expressiveness" (Brabant and Mooney as cited in Dodson and Belk 1996) plays a significant part. As a "ceremonial token" (Ellis and Morrison 2005), greeting cards - purposefully or unintentionally - transmit stereotypical images about the aging process, old age, the elderly, etc. Some of these images are particularly persistent and largely independent of many changes in the society - in a study based on an analysis of 195 humorous birthday cards Vasilikia Demos and Ann Jache (1981) showed that negative portrayal of aging prevails, and an analysis of textual messages of 150 age-specific birthday cards performed by Ellis and Morrison (2005) a quarter of a century later confirmed the hypothesis that negative portrayal of aging is dominant.

\section{HUMOR FROM THE AGE AND GENDER PERSPECTIVE}

Although humor is a cultural universal, correct understanding of particular humorous forms and content presupposes thorough knowledge of the cultural context and its relevant elements. In this case, it includes "cultural specific discourses, stereotypes and symbols" related to particular topics (Andrew 2012: 11). Driessen (as cited in Shifman 2007: 189) points out that topics like sexuality, gender, language, religion, age, politics and ethnicity are globally the most frequent inspiration for humor. Shifman (2007: 189) distinguishes between "globally oriented humorous texts", which are based on "features or social categories that are common to societies all over the world" (sex, gender, age, etc.), and "locally oriented" humor, based on "local categories and cultural patterns", where language, ethnicity and politics are the most frequent topics.

One of the core features of humor is that it is a "shared experience" which permeates our everyday conversations (Foot and McCreaddie 2006: 298), and, being an important factor in face-to-face interactions, it produces multiple significant psychological and social consequences. According to Charles E. Case and Cameron D. Lippard (2009: 241), humor - mediated through various media - at first sight primarily serves as fun, but it is also an important generator and communicator of meanings in the everyday life, "a significant weapon in interpersonal and intergroup conflict and competition" (Case and Lippard 2009: 240), and a significant group cohesive factor that can reinforce the solidarity between members of a particular group (Andrew 2012: 13). Case and Lippard (2009: 240-241), dealing with "humorous assaults on patriarchal ideology", emphasize the emancipatory and subversive component of humor, especially when it is meant to "symbolically redefine gender roles, attitudes, and stereotypes", "to challenge male domination and patriarchal social organization", and to articulate the intention to change the status of women. 
"Humor has great potential for the study of aging" (Nahemow 1986a: xv), but this potential has not been sufficiently recognized or studied - it is only clear that it is vast because "humor is a very complex phenomenon involving cognitive, emotional, physiological, and social aspects" (Martin as cited in Foot and McCreaddie 2006: 293). Keeping in mind this complexity, in addition to suggesting a distinction between "humor about age", i.e. humor that is created by young, middle-aged or older people and "humor intended for a particular age group", Lucille Nahemow (1986b: 4) mentions a number of other significant characteristics of humor: humor is a matter of individual taste - one person may consider something funny and another not at all; there are "differences in the perception of humor" with regard to age; "a sense of humor" is subject to change, and should be regarded in context (leisure, work, socializing with friends, presence of unknown persons, etc.). On the individual level, humor has a variety of functions (Rosenberg 1986: 178): it helps release or discharge internal tensions; it makes it easier to cope with difficult life situations and circumstances; it enables articulating difficult, problematic or even dangerous feelings and/or ideas; it provides a feeling of superiority in relation to other individuals/groups or situations, etc. Social aspects of humor are also significant. Edwin Rosenberg (1986: 177) discusses classical anthropological and sociological approaches to humor which concentrate on the so-called "joking relationship" as well as on various social situations and relations that can generate humor in its various forms.

Concepts and images of aging are part of many forms of humor (such as jokes, cartoons, birthday cards), and were the focus of different studies (Demos and Jache as cited in Kelly et al. 1987: 245). Taking into consideration that earlier analyses determined that age humor is most frequently negative, many researchers have reached the conclusion that negative attitudes towards aging, old age and the elderly prevail in the Western society (Kelly et al. 1987). Humorous birthday cards contain messages ranging from "light humor" and "mild teasing" all the way to "downright insulting" (Bearon 2005: 58), and age humor often becomes explicitly ageist humor. According to Andrew (2012: 14), ageist humor is based on "discourses and stereotypes" about aging and old age understood and accepted by both the sender and the receiver - this symmetry is one of the minimal conditions of communicative efficiency. Given its dominant characteristics, ageist humor can be considered a type of "disparagement humor" (Ford, Richardson and Petit 2015). In this type of communication, eliciting amusement is largely based on denigration or disparagement of the target (Ford, Richardson and Petit 2015: 171). Given that it is to be taken as (just) a joke, it makes it seemingly benign, and this type of humor can largely escape being challenged or criticized (ibid.). What additionally contributes to this "immunity" to criticism is what Robert Butler (1980: 8), the father of the notion of ageism, also touched upon: the fact that these forms of prejudices, discriminatory and institutional practices and policies, in contrast to other discriminatory practices in society, are based on widely held, explicit or implicit attitudes and practices against the elderly, which include old age, and aging. They infiltrate everyday life, and the society treats them as customary, commonplace and "normal" (Snellman, Johansson and Kalman 2012: 21). Initial analyses of jokes about 
aging were conducted as early as 1971 by Erdman B. Palmore, who also pointed out that humor about aging and old age largely manifested itself through negative attitudes and stereotypes, whereas ambivalent and positive attitudes were in a minority (Palmore 2006: 557). Palmore's content analysis of jokes about aging showed that negative jokes most frequently deal with the following motifs: physical and mental capabilities, appearance, age concealment and "old maids" (where a double standard was apparent with regard to ageing and gender - jokes at the expense of older women were generally more negative than those that targeted older men) (Palmore 1971). Similar analyses were published by Shannon R. Ellis and Todd G. Morrison (2005), who analyzed 150 age-specific printed birthday cards, and concluded that $66.7 \%$ of them present aging in a negative way in their textual messages.

When is a joke about aging or old age ageist? How do we recognize ageism? Palmore (2006: 558) says that, if we want to test a joke for ageism, it is sufficient to do a simple experiment: one needs to try to retell it without reference to age, and if it is no longer funny after this reduction, then it is an ageist joke. He also presents a list of motifs that dominate humor based on age prejudices: longevity (or its lack), physical capabilities and appearance, sexual (in)ability, age concealment (most frequently with regard to women), retirement and memory loss (Palmore 2006: 558).

Dealing with constructions of age in ageist humor, Patricia Andrew (2012) focused on email humor. Andrew uses incongruity theory ${ }^{7}$ to explain the interesting fact that ageist emails are mostly shared by the elderly, and superiority theory in those cases where younger people send ageist jokes to older people (Andrew 2012: 12-13). Patricia Andrew's (ibid.: 20) belief that ageist humor can employ positive stereotypes, so that, for instance, an elderly person who is "robust, mentally quick, sexually active" etc. can be regarded as atypical, i.e. as a (positive) exception from the general population of the elderly. In this way, a compliment to a particular elderly person conceals the implicit degradation of the elderly as such.

\section{METHODOLOGY}

It is not difficult to agree with the claim that "proliferation of electronic data via social media, traditional media on the Internet and digital translations of audio and video content provides a rich and vast source of data for analysis" (Neal 2013: 1). The internet is not only the "carrier' of old humor" but also a "generator' of new humor types"; however, in this regard, one should keep in mind Limor Shifman's (2007: 187) statement that this

\footnotetext{
7 Incongruity theory focuses on "the absurd, the unexpected, and the inappropriate or out-of-context events as the basis for humour" (Foot and McCreaddie 2006: 295) or as "the source of amusement" based on "the juxtaposition of two paradoxical, ambiguous or unexpected ways of looking at a situation" (Andrew 2012: 12).
} 
is mostly humor in English, which reflects Western values and priorities of capitalist culture, which is openly youth-oriented. An excellent method of "systematic text analysis" (Mayring 2000: 1) is qualitative content analysis, because it provides insight into manifest or "primary content", i.e. "themes and main ideas of the text", on the one hand, and "latent content" or "context information" on the other (Becker and Lissmann as cited in Mayring 2000: 2). Earlier analyses of birthday cards were limited to printed cards available for purchase (most frequently at the locality where the researcher lived), but the development of internet services and the online market brought about the development of "internet industry" of various types of greeting cards. Therefore, we entered "humor birthday cards" into the Google search engine, and selected two websites from the results: Funky Pigeon and Scribbler. These are British websites specialized in humorous greeting cards of any type. The analysis included the verbal content of 447 internet birthday cards, taking into consideration only age-specific birthday cards that mark an anniversary birthday from the age of forty to the age of one hundred. Certain verbal messages are repeated, often with slight variation in the graphical or visual content. ${ }^{8}$ In this paper, we focus on the verbal aspect of the message.

After multiple readings of the verbal content of the birthday messages, we identified key topics and organized them into coherent categories, and then identified subcategories, i.e. "smaller, more defined categories" (Taylor-Powell and Renner 2003: 3, 7) within them. Four major categories of birthday messages were defined:

1. Old age as decline - cards whose verbal message is based on the narrative of aging and old age as physical and mental decline which, in harmony with this basic idea, contains negative stereotypes about old age, aging, and/or the elderly.

2. Successful aging - cards whose verbal message is based on the narrative of successful aging, and which contain positive stereotypes about old age, aging and/or the elderly.

3. Ambivalent - cards which do not contain an unambiguous attitude concerning old age, aging and/or the elderly. This is primarily achieved by combining the elements from the first two categories (decline and successful aging) or by being directed at people older than 40, but visually referring to a younger age (frequently exploiting gender stereotypes or sexist imagery). This group also contains cards characterized by dissonance between the verbal and the visual content of the message so that, for instance, the verbal part may be neutral, whereas the visual part transmits a negative image of aging/old age. Moreover, the verbal part of the message may be age-neutral, and the visual content sexist (e.g. objectivizing portrayal of women or parts of the woman's body).

4. Age neutral - cards which transmit a verbal message that is not age-specific, applicable to any age.

${ }^{8}$ Out of 184 messages with a negative verbal content, 119 of them are verbally repeated, with a variation of the visual content, and out of 47 messages which are verbally based on the narrative of successful ageing, 12 are repeated. 
The analysis showed that out of the total of 447 analyzed cards, 184 (41.16\%) were based on the narrative of aging and age as decline, 47 (10.52\%) transmitted the narrative of successful aging and old age, 38 (8.50\%) were ambivalent, and 178 (39.82\%) were age-neutral.

\section{OLD AGE AND AGING: REFLECTION OF THE NARRATIVE OF DECLINE}

The narrative of old age/aging as decline and general deprivation is evident in a negative portrayal and interpretation of aging (especially its physical aspects), old age understood as a life period which is primarily characterized by "non-productivity ... passivity and dependency" (on other people) (Sandberg 2013: 11) and age-related messages that negatively characterize the elderly and the process of aging (Bearon 2005). Within this category of birthday cards, we identified several smaller categories and subcategories (Taylor-Powell and Renner 2003), which were deconstructed during the decoding process into smaller (lower) subcategories or sub-subcategories [which partially coincide with the earlier results by Lucille B. Bearon (2005), Shannon R. Ellis and Todd G. Morrison (2005) as well as Patricia Andrew (2012)]:

1) Chronological age and old age:

- Equating old age with chronological age (for instance, "It's your big important birthday. Basically, you're old").

- Chronological age as the source of negative commentaries/reactions of the sender (for instance, "Holy crap. You're old!")

- Consoling and encouraging the receiver because of his/her chronological age (for instance, "40 Today Name? Relax! It's only a number! Even if it is a pretty big one! ").

- "Trivializing" the importance of chronological age (for instance, "Happy Birthday Name 40 today. You're not 40. You're just 21 with 19 years' experience").

- Concealing and reducing chronological age (for instance, "I'm such a good friend. I won't mention your age").

- Aging as the cause of sadness, stress and anxiety that the receiver neutralizes by alcohol (for instance, "There comes a time in every woman's life when the only thing that helps is a glass of champagne"). ${ }^{9}$

2) Negative images of old age:

- Old age (sadness, passivity, suffering) vs. youth (happiness, activity, hedonism) (for instance, "Suddenly Name was struck by a thought: he was shopping with his Wife, in Marks and Spencer and he was looking at cardigans. His life was over").

${ }^{9}$ This is a saying by the very well-known American actress Bette Davis (1908-1989). 
- Decrease in life strength and psychophysical decay (for instance, the use of constructions "over the hill", "downhill" etc.)

- Physical changes or "loss of physical abilities" (Andrew 2012: 15) (for instance, "Happy Birthday Name. For his big Birthday, Name received a sex manual for the over 50s").

- Loss of physical attractiveness and/or attempting to preserve a youthful appearance (for instance, "Being fifty is that point in life where, when your wife tells you to pull in your stomach, you already have").

- Mental changes (for instance, "70 today! In her 70 years she's heard it all, seen it all and done it all. Unfortunately, Name had also forgotten it all").

- Death and dying (for instance, "Old and alone... Waiting for death").

3) Midlife crisis (for instance, "Happy 40th birthday! Although Name was getting on he still behaved like a kid... One or two bottles and he's talking gibberish, dribbling over himself and then falling asleep").

4) Negative portrayal of the elderly:

- Stereotypical characteristics of the elderly (for instance, "Happy Birthday Name To the Original grumpy old man! 60").

- Stereotypical concepts of emotional states of the elderly (for instance, "Turning 40. I can say my school days were the happiest days of my life; which gives you some idea of the misery I've endured over the past 25 years").10

- Lifestyle of the elderly (for instance, "Relax! Bingo is the new rock $n$ roll").

- Old age as a dominant status and label (for instance, "Hello Name Yes you! The old one!").

- "Obsolescence" (cf. Bearon 2005: 59) (for instance, the use of attributes such as "vintage", "ancient", "old timer", "fossil" or referring to places such as museums or Jurassic Park - "Information: Name the museum called, they want their prehistoric relic back. (Happy birthday BTW.)".

\section{YOUTHFUL AGING: THE REFLECTION OF THE NARRATIVE OF SUCCESSFUL AGING/OLD AGE}

The narrative of successful aging is based on promoting "agelessness", youthfulness and the standards of "midlife" (Sandberg 2013). Linn Sandberg emphasizes the growing popularity of this narrative in the last fifteen or so years, pointing out the importance of the economic, political and socio-cultural context within which it was created and started its "victorious" global tour. It is a neoliberal anti-aging imaginary based on the imperatives of "activity, autonomy and responsibility" (ibid.: 13). And while the narrative of aging and old age as decline is a generator of negative stereotypes and prejudices and discriminatory

\footnotetext{
${ }^{10}$ This is a saying by British writer, actor and presenter Paul Merton.
} 
practices towards the elderly, the narrative of successful aging can be a source of positive ageism (for instance, seeing old age as the time of achieving perfection, life wisdom, maturity and accumulated experience, or even the beginning of a real, authentic and fulfilled life and fun) (Bearon 2005: 59). We have already mentioned Patricia Andrew's claim (2012: 20 ) that humor based on positive stereotypes of a "successful" elderly person (attractive, "mentally quick, sexually active" etc.) contains a concealed ageist edge because, insisting on the atypicality of this person, it implicitly degrades the general population of the elderly.

The analysis found 47 messages that were based on the narrative of youthful and successful aging. As in the previous category, the following subgroups were constructed:

1. Youthful and attractive physical appearance of the elderly person (for instance, "You're 40 and still looking good for a feckin'old person”, also see the example under (2)).

2. Modern and glamorous style (for instance, "Happy 50th Birthday, Name - Stylish, Charming, Desirable, Eligible, Classy, Gracious, Sexy, Chic, Sassy, Alluring, Witty, Intelligent, Articulate, Fabulous").

3. Mental characteristics (see example under (2) - "Witty, Intelligent, Articulate").

4. (Positive) personality of the older person (for instance, "Glorious, Magnificent, Sensational at 60 Name (blockbuster)").

5. Age as a personal choice / "age is a matter of mind" (Ellis and Morrison 2005: 67) or heart (for instance, "News! To a very special and wonderful woman happy birthday! Young At Heart! 80 today! ...").

6. Paternalistic names for the elderly (for instance, "Happy 80th birthday Name Surname! A true classic! A Golden Oldie! 80 today! Name Surname. Birthday Bumps! Not at my age says Name!").

7. Age inappropriate terms and animalistic comparisons (for instance, “...80 today! Name Surname. World exclusive! Birthday Girl! ..."; "Spring Chicken Name 80").

8. Aging as maturing (for instance, "Christopher was like wine: he reached perfection with age").

9. Aging and the more prominent social status (for instance, "Andrew isn't growing old, he's just becoming more important").

\section{DECAY VS. SUCCESS - AGE-RELATED (AND GENDER-RELATED) HUMOR BETWEEN TWO EXTREMES}

Our analysis of age-specific humorous birthday cards shows a prevalence of verbal message that present old age, aging and the elderly in a negative way, in the context of the narrative of old age as decay, whereby some aspects also show the perpetuation of ingrained 
gender stereotypes. Such age messages tend to reduce age solely to chronological age, whereby the fortieth birthday, and any birthdays after that, cause a number of unpleasant reactions (astonishment, outrage, cursing of the sender, and sadness and stress of the receiver) and negative comments, as well as consoling, appeasing and encouragement and reduction of the importance of chronological age. Certain cards suggest that the recipient can relieve the sadness, anxiety and stress over his/her age, at least to some degree, by consuming alcohol. The number of cards exploiting the motif of concealing or reducing one's own or someone else's age testifies to the fact that chronological age, at some point, becomes a problem in social interactions. In this regard, the gender component (once more) comes to the fore - all aspects of concealing chronological age are related exclusively to aging women, which indicates social disqualification of older women and the gendered double standard of aging (Sontag as cited in Geiger Zeman 2014; Calasanti 2005).

In the context of the narrative of aging/old age as decay, the analyzed birthday cards portray old age as a life period contrasted with youth - youth is the time of happiness, hedonism, attractiveness, whereas in old age, as a time of suffering, the person becomes but a passive observer and evaluator of his/her earlier, younger and "full" life. The analyzed cards show the importance of the gender component in this respect as well, because aging in men is interpreted as a type of "losing once edge" or even "feminization" or "demasculinization" - from one's youth as the period of unconstrained excessive hedonism to one's old age as monotonous everyday life, overeating (on unhealthy food), passivization and retreat into the private sphere of family and married life.

Birthday cards that humorously portray age and aging as the decrease in (psycho) physical strength and vigor in general, elaborate on the topic through motifs of unwanted physical and mental changes (for instance, slowing down of motor skills, flat feet, rheumatism, memory loss, disorientation, etc.) and expecting dying and death. Intimate biological, physical and psychological phenomena and processes are necessarily socio-culturally reworked or reinterpreted: "meanings assigned to age are culturally determined" (Heath 2009: 4). Many theories and studies convincingly showed that the western culture is turned mostly (if not exclusively) towards the glorification of youth (Geiger Zeman and Zeman 2014), so that physical changes like sagging breasts, gray pubic hair, baldness, increase in body mass, loss of hearing or vision ${ }^{11}$ - like old age and aging in general - become something to be anxious about, something to be ashamed of, because they deviate so considerably from the dominant ideals of body functionality, health and physical activity. However, in this respect too, women have it more difficult, because they are more exposed to critical looks and sharp commentaries than men (Russell Hatch 2005).

Ageist humor suggests that persons of both genders after the age of forty face physical changes that the dominant culture defines as a loss in physical attraction, but these changes are evaluated on the basis of double standards. In a culture that, on the one hand, places emphasis on the importance of physical appearance in women (but not

${ }^{11}$ These are physical changes that are mentioned in the analyzed birthday cards. 
in men), and, on the other, defines physical attraction solely through youth and youthful appearance (Wolf 2008; Calasanti 2005; Hurd Clarke and Korotchenko 2011), women try to fight against the loss of physical attraction by using cosmetic interventions. Therefore, it is no wonder that the analyzed cards insist on esthetic categories and attractive physical appearance much more pronouncedly in the case of women. Of course, men are not spared the hardships brought about by the physical aspects of being, but their physical changes are viewed more in terms of functionality (including the sensitive area of sexual ability) (Marshall and Katz 2012), while the ideal of hegemonic masculinity puts to the fore the requirements of acquiring and retaining power, control, and, of course, independence (Hurd Clarke and Korotchenko 2011).

An important humorous motif in birthday cards is the so-called midlife crisis, which, in a more or less dramatic way, marks the beginning of old age..12 The "crisis" character of this period in life (or turning point) is frequently manifested in a certain infantilization (as an unconscious attempt to somehow "bypass" or ignore the passage of time) or a (futile) attempt to "return" to the past. This "strategy" has a gender component, because it is connected with immature and infantile behavior of men in their forties trying in vain to recreate their youth.

Humorous birthday cards based on the narrative of old age as decay portray the elderly as obsolete, ${ }^{13}$ and exploit a range of negative age stereotypes and invalid generalizations about the characteristics of the elderly (grumpiness, nagging), dominantly "elderly" emotional states (misery, sadness), alleged characteristics of an "elderly" way of life (immobility, passivity, focus on life in the private sphere, practicing typically "elderly" activities such as playing bingo, smoking a pipe, using slippers as their main footwear, etc.). In this context, old age is related to specific institutions (e.g. museums), popular-culture localities (e.g. the Jurassic Park) or expressions (e.g. "over the hill", "downhill"), whereas people older than 40 (!) are explicitly or implicitly characterized using derisive, negative expressions - "old timer", "fossil", "vintage", "pickled", "prehistoric relic", etc., where the verbal content of such birthday cards suggests that a person's chronological age becomes their main characteristic or their dominant status that eliminates any other characteristics they may have in social interactions (Andrew 2012: 19). As we have said, this happens roughly from the fortieth birthday on - after this threshold, the person faces being directly and unambiguously characterized as old (ibid.: 20).

\footnotetext{
${ }^{12}$ Freund and Ritter (2009: 582) point out that "the midlife crisis" is "the most popular concept" to describe "middle adulthood", and is based on the idea of the individual facing the finiteness of time that he/she has left until death, which leads to making a sort of a balance sheet of (un)realized goals and achievements, and taking "drastic measures" to fulfill unfulfilled dreams. There is no consensus on when middle age starts, and double gendered standards, as mentioned by Heath (2009) are also present. The concept of "midlife crisis" has not been fully accepted - its critics point out that it is a social construct and a concept that is not only insufficiently studied, but its existence is denied by some research results, suggesting that "middle adulthood" should be seen "just [as] a particularly challenging phase of life" (Freund and Ritter 2009: 588).

${ }^{13}$ Bearon (2005: 59) in his analysis of birthday cards points to "obsolescence" as a characteristic that is frequently ascribed to the elderly and ageing.
} 
In contrast, some birthday cards generate humor based on the narrative of successful aging, which plays with positive age stereotypes. These positive stereotypes, in some of their aspects, challenge and refute the deep-seated negative stereotypes and concepts of old age, aging and the elderly. In this narrative, old age is no longer a gradual and inexorable process of decay, but a linear process of growth and accumulation of wisdom, maturity, experience, style, etc. Birthday cards based on the successful aging narrative emphasize youthful and attractive physical appearance of women; mental capacities, modern style and an atypical personality of an elderly person; prominent social status of men; with evident use of paternalistic labels (for instance, "a golden oldie", "a true classic", "a fine vintage", etc.), age-inappropriate expressions (for instance, girl) and animalistic comparisons (for instance, "a spring chicken", etc.).

In the successful aging narrative, there is evidence of distinguishing between gender roles and identities (Leontowitsch 2012: 107-108; Calasanti 2005: 10; Zeman and Geiger Zeman 2015). Thus, the motif of youthful physical appearance prevails in birthday cards aimed at women, whose attractiveness, glamour, elegance and modernity is atypical of their generation. Such treatment does not bypass men, interestingly, exclusively if they are fathers. These types of messages clearly show that birthday cards, in fact, communicate stereotypical messages about gender roles and gender expectations (Loughran 2010: 633).

Verbal messages in birthday cards suggest that the recipient's personality diverges from the deep-seated negative stereotypes about the elderly as constantly grumpy or unhappy individuals (which is the basis of the narrative of old age as decay). In the context of the narrative of successful aging, the old person has the chance to remain "amazing", "fabulous", "wonderful", "stylish", "sexy", "chic", "dazzling, "desirable", etc., which includes an active attitude because "age is a matter of mind" (Ellis and Morrison 2005: 67) or heart, as well as of various types of investments to keep and preserve their special status (for instance, investing in clothes, keeping up with fashion and other trends, etc.).

The idea of old age as growth and a sort of a lifelong evolution process, which culminates in perfection at old age ("aged to perfection"), most frequently compared with the aging of premium wine and "a fine vintage", has a gender dimension - it refers exclusively to men. Whereas older women are treated as successful only if they are "stylish", youthful in appearance, charming and glamorous, positive portrayals of elderly men connect successful aging primarily with increase in their social importance.

\section{CONCLUSION}

Weber and Cameron (1979) (as cited in Palmore 2006: 558) believe that, to put it colloquially, tastes differ - what one person considers negative, another may not, which brings them to the conclusion that even negative messages in age-related humor may have positive psychological, physiological and social functions. They can be a release from 
repressed fears, they may help people cope with (their own) aging and mortality more easily (Andrew 2012: 21), reduce anxieties and fears about growing older, allow easier coping with taboos such as old age and death, defuse sensitive situations, function as a way of social criticism, etc. (Palmore 2006: 557-559). On the other hand, we completely agree with Patricia Andrew's (2012: 21) statement that one of the consequences of negative stereotypes about old age and the elderly (mediated through any means of communication) is the tendency of the elderly person to "internalize negative discourses" about old age and aging, and to accept them as "normal", and, somewhat paradoxically, adopt the characteristics that they believe are typical of and socially desirable for their age group. In this way, age stereotypes are supported and ageism is perpetuated (ibid.: 22), and with them a number of collateral gender stereotypes. In this context, it should be reiterated that even positive ageism has its negative sides and consequences, because in addition to supporting the anti-aging industry and an anti-aging worldview (Sandberg 2013), it can cause the feeling of lack of success or dissatisfaction in those elderly persons who cannot (or do not want to) comply with the promoted ideals of activity, independence and power.

Of course, all the mentioned positive and negative effects of age-related humor present in birthday cards should be seen in a particular temporal and socio-cultural context because, in the short term, age-related humor - whether in the form of mild teasing or open offense - can amuse and alleviate fears of one's own transience and mortality, but in the long term, it supports and strengthens ageism as a "normal" social phenomenon, and supports distorted socio-cultural images of aging, including harmful gender asymmetries.

\section{NOTE}

This text is based on the presentation entitled "Aging is mandatory, and growing up is not' - the images of old age, age humor and internet birthday cards" presented by Marija Geiger Zeman and Zdenko Zeman at the conference with international participation "'Who laughs last did not get the joke': humor in everyday communication" held at the Institute of Ethnology and Folklore Research in Zagreb, 19-20 November 2015.

\section{REFERENCES AND SOURCES}

Andrew, Patricia. 2012. "Laughter is the Best Medicine'. The Construction of Old Age in Ageist Humor". In Language and Humour in the Media. Jan Chovanec and Isabel Ermida, eds. Newcastle upon Tyne: Cambridge Scholars Publishing, 11-24.

Bearon, Lucille B. 2005. "Cards". In Encyclopedia of Ageism. Erdman B. Palmore, Laurence Branch and Diana K. Harris, eds. New York, London, Oxford: Haworth Pastoral Press, Haworth Reference Press, 58-60.

Butler, Robert N. 1980. "Ageism. A Foreword". Journal of Social Issues 36/2: 8-11. [https://doi. org/10.1111/j.1540-4560.1980.tb02018.x] 
Calasanti, Toni. 2005. "Ageism, Gravity, and Gender. Experiences of Aging Bodies". Generations 29/3: 8-12.

Carrier, James G., ed. 2005. A Handbook of Economic Anthropology. Cheltenham, Northampton: Edward Elgar Publishing Limited.

Case, Charles E. and Cameron D. Lippard. 2009. "Humorous Assaults on Patriarchal Ideology". Sociological Inquiry 79/2: 240-255. [https://doi.org/10.1111/j.1475-682X.2009.00282.x]

Caplow, Theodore. 1984. "Rule Enforcement Without Visible Means. Christmas Gift Giving in Middletown". American Journal of Sociology 89/6: 1306-1323. [https://doi.org/10.1086/228017]

Chovanec, Jan and Isabel Ermida, eds. 2012. Language and Humour in the Media. Newcastle upon Tyne: Cambridge Scholars Publishing.

Clarke, Alison J. 2007. "Consuming Children and Making Mothers. Birthday Parties, Gifts and the Pursuit of Sameness". Horizontes Antropológicos 13/28: 263-287. [https://doi.org/10.1590/s010471832007000200011]

Cruikshank, Margaret. 2009. Learning to be Old. Gender, Culture, and Aging. Lanham etc.: Rowman and Littlefield Publishers, Inc.

Demos, Vasilikie and Ann Jache. 1981. "When You Care Enough. An Analysis of Attitudes toward Aging in Humorous Birthday Cards". The Gerontologists 21/2: 209-215. [https://doi.org/10.1093/geront/21.2.209]

Dill, Karen E., ed. 2015. The Oxford Handbook of Media Psychology. Oxford: Oxford University Press.

Dodson, Kimberly J. and Russell W. Belk. 1996. "The Birthday Card Minefield". In NA-Advances in Consumer Research 23. Kim P. Corfman and John G. Lynch, Jr., eds. Provo, UT: Association for Consumer Research, 14-20. Available at: http://acrwebsite.org/volumes/7860/volumes/v23/NA-23 (accessed 15 December 2015).

Ellis, Shannon R. and Todd G. Morrison. 2005. "Stereotypes of Ageing. Messages Promoted by AgeSpecific Paper Birthday Cards Available in Canada". International Journal of Aging and Human Development 61/1: 57-73. [https://doi.org/10.2190/ULUU-UN83-8W18-EP70]

Foot, Hugh and May McCreaddie. 2006. "Humour and Laughter". In The Handbook of Communication Skills. Owen Hargie, ed. London: Routledge, 293-322.

Ford, Thomas E. Kyle Richardson and Whitney E. Petit. 2015. "Disparagement Humor and Prejudice. Contemporary Theory and Research". Humor 28/2: 171-186. [https://doi.org/10.1515/humor-2015-0017]

Freund, Alexandra M. and Johannes O. Ritter. 2009. “Midlife Crisis. A Debate”. Gerontology 55/5: 582591. [https://doi.org/10.1159/000227322]

Funky Pigeon. Available at: https://www.funkypigeon.com/ (accessed October 2015).

Geiger Zeman, Marija and Zdenko Zeman. 2011. "Suveniri - simboli lokalnih identiteta, ekspresije kulturne baštine i promotori turizma". Proceedings from the International conference Modeli upravljanja procesima obnove i razvoja povijesnih gradova - Primjer Ivanić-Grada: Mogućnosti revitalizacije i obnove starog Ivanića, paper 44: 1-15. Available at: https://bib.irb.hr/datoteka/537823.D44_GeigerZeman_Zeman.pdf (accessed 4 February 2016).

Geiger Zeman, Marija and Zdenko Zeman. 2014. "Who's Afraid of Baba Yaga? A Reading of Ageing From the Gender Perspective". Narodna umjetnost 51/1: 223-244. [https://doi.org/10.15176/vol51no111]

Geiger Zeman, Marija. 2014. "Kažu da prije stare žene nego muški' - starost i starenje kao relevantna feministička pitanja”. Treća: časopis Centra za ženske studije 16/1-2: 5-11.

Greeting Card Association. s.a. "About the Industry". Available at: http://www.greetingcard.org/abouttheindustry/history/tabid/72/default.aspx (accessed 15 March 2016). 
Greeting Card Association. s.a. "Facts and Figures. Latest Figures from the GCA Market Report 2015". Available at: http://www.greetingcardassociation.org.uk/resources/for-publishers/the-market/factsand-figures (accessed 15 March 2016).

Gullette, Margaret M. 2015. "Aged by Culture". In Routledge Handbook of Cultural Gerontology. Julia Twigg and Wendy Martin, eds. London: Routledge, 21-28.

Heath, Kay. 2009. Aging by the Book. The Emergence of Midlife in Victorian Britain. New York: State University of New York Press, Albani.

Hurd Clare, Laura and Alexandra Korotchenko. 2011. "Aging and the Body. A Review". Canadian Journal on Aging 30/3: 495-510. Available at: http://www.ncbi.nlm.nih.gov/pmc/articles/PMC4072651/ (accessed 14 November 2015).

Kelly, Lynn E., V. Jane Knox, William L. Gekoski and Kathryn M. Evans. 1987. "Age-Related Humor as an Indicator of Attitudes and Perceptions". The Journal of Social Psychology 127/3: 245-250. [https:// doi.org/10.1080/00224545.1987.9713690]

Leonardo, Micaela di. 1987. "The Female World of Cards and Holidays. Women, Families, and the Work of Kinship". Signs 12/3: 440-453. [https://doi.org/10.1086/494338]

Leontowitsch, Miranda, ed. 2012. Researching Later Life and Ageing. Expanding Qualitative Research Horizons. Hampshire, New York: Palgrave Macmillan.

Leontowitsch, Miranda. 2012. "Interviewing Older Men”. In Researching Later Life and Ageing. Expanding Qualitative Research Horizons. Miranda Leontowitsch, ed. Hampshire, New York: Palgrave Macmillan, 104-123. [https://doi.org/10.1057/9781137271372_7]

Loughran, Hilda. 2010. "Eighteen and Celebrating. Birthday Cards and Drinking Culture". Journal of Youth Studies 13/6: 631-645. [https://doi.org/10.1080/13676261003801721]

Marshall, Barbara L. and Stephen Katz. 2012. "The Embodied Life Course. Post-ageism or the Renaturalization of Gender?” Societies 2/ 222-234.

Mayring, Philipp. 2000. "Qualitative Content Analysis". Forum Qualitative Sozialforschung / Forum: Qualitative Social Research 1/2. Available at: http://www.qualitative-research.net/index.php/fqs/ article/view/1089/2385 (accessed 7 April 2016).

Morgan, Leslie and Suzanne Kunkel. 2001. Aging. The Social Context. Thousand Oaks etc.: Pine Forge Press.

Nahemow, Lucille, Kathleen A. McCluskey-Fawcett and Paul E. McGhee, eds. 1986. Humor and Aging. Orlando, Florida, London: Academic Press, Inc.

Nahemow, Lucille. 1986a. "Preface". In Humor and Aging. Lucille Nahemow, Kathleen A. McCluskeyFawcett and Paul E. McGhee, eds. Orlando, Florida, London: Academic Press, Inc., xv-xvii. [https:// doi.org/10.1016/B978-0-12-513790-4.50005-4]

Nahemow, Lucille. 1986b. "Humor as a Data Base for the Study of Aging". In Humor and Aging. Lucille Nahemow, Kathleen A. McCluskey-Fawcett and Paul E. McGhee, eds. Orlando, Florida, London: Academic Press, Inc., 3-26. [https://doi.org/10.1016/B978-0-12-513790-4.50008-X]

Neal, Michael R. 2013. "Media Content Analysis. Qualitative Methods". In The Oxford Handbook of Media Psychology. Karen E. Dill, ed. Oxford: Oxford University Press, 1-26.

Palmore, Erdman. 1971. "Attitudes Toward Aging as Shown by Humor". The Gerontologist 11/3: 181-186. [https://doi.org/10.1093/geront/11.3_Part_1.181]

Palmore, Erdman B., Laurence Branch and Diana K. Harris, eds. 2005. Encyclopedia of Ageism. New York, London, Oxford: Haworth Pastoral Press, Haworth Reference Press. 
Palmore, Erdman B. 2006. "Humor". In The Encyclopedia of Aging, 1 (A-K). Richard Schulz, Linda S. Noelker, Kenneth Rockwood and Richard L. Sprott, eds. New York: Springer Publishing Company, 557-559.

Rogan, Bjarne. 2005. "An Entangled Object. The Picture Postcard as Souvenir and Collectible, Exchange and Ritual Communication". Cultural Analysis 4: 1-27. Available at: http://socrates.berkeley. edu/ caforum/volume4/pdf/rogan_150ppi.pdf (accessed 20 February 2016).

Rosenberg, Edwin. 1986. "Humor and the Death System. An Investigation of Funeral Directors". In Humor and Aging. Lucille Nahemow, Kathleen A. McCluskey-Fawcett and Paul E. McGhee, eds. Orlando, Florida, London: Academic Press, Inc., 175-198. [https://doi.org/10.1016/B978-0-12-5137904.50018-2]

Russell Hatch, Laurie. 2005. “Gender and Ageism”. Generations 29/3: 19-24.

Sandberg, Linn. 2013. "Affirmative Old Age. The Ageing Body and Feminist Theories on Difference". International Journal of Ageing and Later Life 8/1: 11-40. [https://doi.org/10.3384/ijal.16528670.12197]

Scribbler. Available at: https://www.scribbler.com/ (accessed October 2015).

Schulz, Richard, Linda S. Noelker, Kenneth Rockwood and Richard L. Sprott, eds. 2006. The Encyclopedia of Aging, 1 (A-K). New York: Springer Publishing Company.

Sherry, John F. Jr. 1983. "Gift Giving in Anthropological Perspective". The Journal of Consumer Research 10/2: 157-168. [https://doi.org/10.1086/208956]

Shifman, Limor. 2007. "Humor in the Age of Digital Reproduction. Continuity and Change in InternetBased Comic Texts". International Journal of Communication 1: 187-209.

Snellman, Fredrik, Stina Johansson and Hildur Kalman. 2012. "A Pilot Study of Birthday Cards as Vignettes. Methodological Reflections on the Elusive Everyday Ageism". International Journal of Humanities and Social Science 2/7: 21-33.

Taylor-Powell, Ellen and Marcus Rennar. 2003. Analyzing Qualitative Data. University of WisconsinExtension: Program Development \& Evaluation. Available at: http://learningstore.uwex.edu/assets/ pdfs/g3658-12.pdf (accessed 18 March 2016).

Twigg, Julia and Wendy Martin, eds. 2015. Routledge Handbook of Cultural Gerontology. London: Routledge.

Wolf, Naomi. 2008. Mit o ljepoti. Kako se prikazi ljepote koriste protiv žena. Zagreb: Naklada Jesenski i Turk.

Wolf, Richard. 2014. "60 is the New 50". Allianz International Pension Issues 3/14: 1-4. Available at: http://projectm-online.com/app/uploads/60_is_the_new_50.pdf (accessed 23 March 2016).

Yan, Yunxiang. 2005. "The Gift and Gift Economy". In A Handbook of Economic Anthropology. James G. Carrier, ed. Cheltenham, Northampton: Edward Elgar Publishing Limited, 246-261. [https://doi.org/ 10.4337/9781845423469.00027]

Zeman, Zdenko and Marija Geiger Zeman. 2015. “'Young' Heart in 'Old’ Body. Experiences of Ageing from Older Persons' Perspective". Etnološka tribina 38/45: 72-85. [https://doi.org/10.15176/vol51no111] 


\section{ZA TVOJ VELIKI I VAŽAN DAN: STAROST, HUMOR I INTERNETSKE ROĐENDANSKE ČESTITKE}

lako je kategorija dobi iznimno kompleksna dob se najčešće reducira na kronološku dob, koja je - kao broj proživljenih godina od trenutka rođenja (broj rođendana) - najjednostavniji marker nečije dobi (ili starosti). Važan aspekt rođendana su i rođendanske čestitke. Riječ je o multifunkcionalnim artefaktima popularne kulture kod kojih je najvažnija komunikacijska funkcija. Na individualnom nivou pošiljatelj rođendanskom čestitkom primatelju/ici šalje određene poruke, a na socio-kulturnom nivou rođendanska čestitka prenosi društveno kreirana značenja i sadržaje o dobi, starosti i starenju. U tom smislu rođendanska čestitka je "ceremonijalni znak" (Ellis i Morrison 2005), koji prenosi (i osnažuje) kulturalne predodžbe, značenja, stavove i poruke, odnosno "diskurse koji formiraju temelje socijalne konstrukcije dobi” (Andrew 2012: 11), pri čemu posebno važnu ulogu ima humor. Ranija istraživanja su pokazala da dobni humor ima pozitivne, ambivalentne i, najčešće, negativne aspekte. Ti negativni aspekti se odnose na dobne stereotipe i iskrivljena značenja koje određena kultura pripisuje starenju i starosti, što uključuje i rodnu komponentu. U radu će biti prikazani rezultati analize sadržaja dobnog humora prisutnog $u$ internetskim rođendanskim čestitkama, a poseban će naglasak biti stavljen na: 1) teme i motive koji ukazuju na dominantne i (globalno) raširene narative o starosti i starenju, socio-kulturne predodžbe, shvaćanja i stavove o starenju, starosti i starim osobama; 2) kratkoročne efekte i dugoročne konzekvence humorističnog sadržaja te vrste.

Ključne riječi: dobni humor, narativi o starenju, internetske rođendanske čestitke, starost, kronološka dob, analiza sadržaja 